\title{
Distribution and Disease Prevalence of Coral Associated Bacteria at Some Impacted Red Sea Reefs
}

\author{
Al-Hammady MAM ${ }^{1 *}$ and Mohamed $\mathrm{MH}^{2}$ \\ ${ }^{1}$ National Institute of Oceanography and Fisheries, Red Sea Brach, Hurghada, Egypt \\ ${ }^{2}$ Faculty of Veterinary Medicine, New Valley, Assuite University, Egypt
}

\begin{abstract}
Prevalence and distribution of coral disease were surveyed in three impacted sites at Red Sea coast. Prevalence were significant difference between studied reefs (ANOVA; $F=10.777, p<0.0001$ ). Sites closed to oil pollution (sites 1 and 2) displayed much higher levels of disease prevalence $(25.3 \% \pm 8.32$ and $18.5 \% \pm 3.1$, respectively), than site 3 that close to landfilling $(12.9 \% \pm 2.1)$. Totally, 99coral braches, representing 20 species affected by at least 12 diseases. However, site 3 is characterized by the highest diversity (Simpson's Index $=0.081$ ) and highest percentage cover of life coral $(35.2 \% \pm 11.4)$ showed the lowest coral diseases number (3). In opposite, 10 coral diseases were recorded at site 1 , and 8 coral diseases at site 2 . While, the coral disease atramentous necrosis attained the highest prevalence percentage at sites 1 and $2(3.2 \%$ and $4.5 \%$, respectively), did not recorded at site 3 . Sediment damage disease recorded the highest prevalence percentage at site $3(5.1 \%)$, but did not record at sites 1 and 2 . Diseases having lowest percentage cover were white band disease (sites 1 and 2) and white tips disease. The most commonly distributed disease (atramentous necrosis) infected five corals in site 1 and six corals in site 2 . The least commonly distributed disease (white tips) infected only two corals (Acropora humilis and Acropora formosa) at site 3 . The genus Porites at sites was particularly vulnerable to all diseases. However, Galaxea fasicularis at site 3 recorded the highest percent cover of sediment damage disease. Coral disease atramentous necrosis is always associated with Vermetidae predation and Tridacna boring. While, Drupels predation is associated with skeletal eroding band. Aggressive filamentous algal overgrowth is associated with sediment damage disease at site 3 . The pathogenic bacterium isolated from the diseased Stylophora pistillata, Porites sp., and Acropora sp., referred to as Vibrio fischeri.
\end{abstract}

Keywords: Coral; Disease prevalence; Distribution; Coral bacteria; Vibrio sp.; Red sea

\section{Introduction}

Globally, we are witnessing on of coral reef decline. An important factor contributing to coral decline is the widespread infectious diseases, especially coral reef of the Red Sea $[1,2]$. Coral disease is an abnormal condition of an organism that causes organism disfunctions, associated with strange symptoms and signs ICRI / UNEPWCMC, 2010. Disease causation may be result from pathogens, environmental stressors, or a combination of biotic and abiotic factors [3]. Biotic diseases are caused by pathogenic microorganisms such as viruses, bacteria, fungi, and protists and are often species-specific $[4,5]$ and infectious [6]. While, abiotic diseases result from natural and anthropogenic stressors associated with exposure to pollutants $[1,7]$. However, biotic diseases may be associated with environmental threats that trigger the pathogenic process, or increase the rate of disease transmission [8,9]. However, Furby et al. [2] reported a strong correlation between the presence of lesion corals and decreased water quality. Other studies suggested a link between snail predators and disease spread such as outbreak of 'white syndrome' in Red Sea acroporid corals correlated with an outbreak in the coral livorous snail Drupellacornus [10]. Exposure to Hermodice carunculata (polychaete) infected with the bleaching pathogen Vibrio shiloi has been shown to induce bleaching in the Mediterranean coral Oculina patagonicain laboratory aquaria [11].

Threats to biodiversity are considered one of the major predicted impacts of new diseases and those infecting multiple species [12]. A relationship between diversity and disease prevalence, as high prevalence of a disease with multiple hosts can lower diversity [8]. In contrast, a high diversity reef could be predicted to be more resistant to an infectious disease, if host species are less abundant. However, previous reports found that most coral diseases affect only a few species [13]. While, the finding of this study and others, Richardson et al. [14], Green and Bruckner [15] and Weil et al. [16], it was reported that the total number of infected species increased with the several of geographical area, and that host breadth of most diseases is wider than previously thought. Sheridan et al. [17] reported that corals from reefs affected by river discharge and terrestrial sediments were more affected by white syndrome than reefs located far from any source of terrestrial run-off. Terrestrial runoff-affected reefs also displayed a wider diversity of coral species affected by this disease. The objectives of this survey were to identify the susceptibility to diseases among the Red Sea coral reefs species, and to determine the disease prevalence that were previously recorded within the country, to develop a species list of hosts affected by each disease observed and to describe any apparently 'new' syndromes or potential diseases. A data based on coral diseases in the area will be established, this will help using coral diseases as indicators of environmental impacts and acting to remove or minimize these impacts.

\section{Material and Methods}

Coral disease distributions and prevalence were studied in three

*Corresponding author: Al-Hammady MAM, National Institute of Oceanography and Fisheries, Red Sea Brach, Hurghada, Egypt, Tel: +201094576510; E-mail: coralreef_niof1@yahoo.com

Received January 01, 2016; Accepted January 23, 2016; Published February 01,2016

Citation: Al-Hammady MAM, Mohamed MH (2016) Distribution and Disease Prevalence of Coral Associated Bacteria at Some Impacted Red Sea Reefs. J Biodivers Endanger Species 4: 158. doi:10.4172/2332-2543.1000158

Copyright: (C) 2016 Al-Hammady MAM, et al. This is an open-access article distributed under the terms of the Creative Commons Attribution License, which permits unrestricted use, distribution, and reproduction in any medium, provided the original author and source are credited. 
impacted sites at the Red Sea coast (Figure 1 and Table 1). These sites were Ras Gharib, Gble Elzyet and Crescent reef in front of National Institute of Oceanography and Fisheries-Hurghada. Surveys were conducted using SCUBA diving and Line Intercept transects (LIT), each covering an area measuring $20 \mathrm{~m} \times 2 \mathrm{~m}$. Five horizontal transects between $10 \mathrm{~m}$ and $12 \mathrm{~m}$ were completed at 7-8 dive locations. Transect were run to obtain a detailed description of substrate composition and the following substrate categories were noted: live hard coral, soft coral, recently killed hard coral, weathered rock with turf algae, rubble, sand, silt, canopy-forming algae and other encrusting organisms (such as sponges, ascidians, gorgonians). Additional information on poaching, pollution sources and other human stressors was obtained by personal observation. Species were identified in situ where possible or small pieces were collected for identification in the laboratory when necessary. Identification of specimens was based on $[18,19]$. Species diversity was determined using Simpson's index of concentration by combining species lists for all transects within a reef. Simpson's index is useful for such sampling as it does not depend on sample size or require a specific type of abundance distribution [20]. All diseased colonies within LIT were noted and the number of diseased vs. healthy colonies per species was counted so that disease prevalence could be calculated.

Disease prevalence was calculated as follows (see explanation above): number of diseased colonies per transect / total number of colonies per transect $\times 100$.

To examine a possible connection between disease prevalence and coral species host abundance, the relative abundance of each species was calculated per reef as the total number of colonies per species as the total number of all colonies and this also allowed a calculation of species abundance relative to all other species. A 2-way ANOVA was used to detect differences in prevalence between sites.

In March 2014, totally 54 colonies from different coral reef species signs disease were haphazardly chosen and collected at $2 \mathrm{~m}$ to $3 \mathrm{~m}$ depth from the studied sites. Different size branches ranging from $1.2 \mathrm{~cm}$ to $3 \mathrm{~cm}$ were tagged and sampled using SCUBA and a long nosed bone cutter. Sample was kept in a separate plastic package under water to be, transported to NIOF laboratory. Each sample was washed twice with $0.2 \mu \mathrm{m}$ filtered and autoclaved sea-water to remove any loosely associated microbes. Branches were crushed using a previously flamed sterilized mortar and pestle and $2 \mathrm{ml}$ of filter sterilized seawater. The resulting mix was homogenized and plated on trypticsoya agar media (Difco) and incubated for no more than $24 \mathrm{~h}$. [21]. The suspected bacterial isolates were isolated, purified using thiosulphate citrate bile salt sucrose agar (TCBS, Difco) and characterized using the standard biochemical method as described by [22]. Commercial miniaturized API 20E galleries (Bio Merieux) were also used according to the manufacturer's instructions.

\section{Results}

A summary of the survey sites is presented in (Table2). We identified a number of diseases and syndromes present on our surveyed reefs;

\begin{tabular}{|c|c|c|c|c|}
\hline & Sites & Latitudes & Longitudes & Possible stressors \\
\hline 1 & Ras Gharib & $28^{\circ} 21^{\prime} 44.62^{\prime \prime} \mathrm{N}$ & $33^{\circ} 5^{\prime} 47.97^{\prime \prime} \mathrm{E}$ & Oil pollution and sewage \\
\hline 2 & Gabel El-Zayet & $27^{\circ} 45^{\prime} 17.85^{\prime \prime}$ & $33^{\circ} 33^{\prime} 47.21^{\prime \prime}$ & Oil pollution \\
\hline 3 & Crescent Reef & $27^{\circ} 17^{\prime} 4.41^{\prime \prime} \mathrm{N}$ & $33^{\circ} 46^{\prime} 36.79^{\prime \prime} \mathrm{E}$ & $\begin{array}{c}\text { Poaching, Swimming and } \\
\text { Landfilling }\end{array}$ \\
\hline
\end{tabular}

Table 1: Latitudes and longitudes of the study sites.

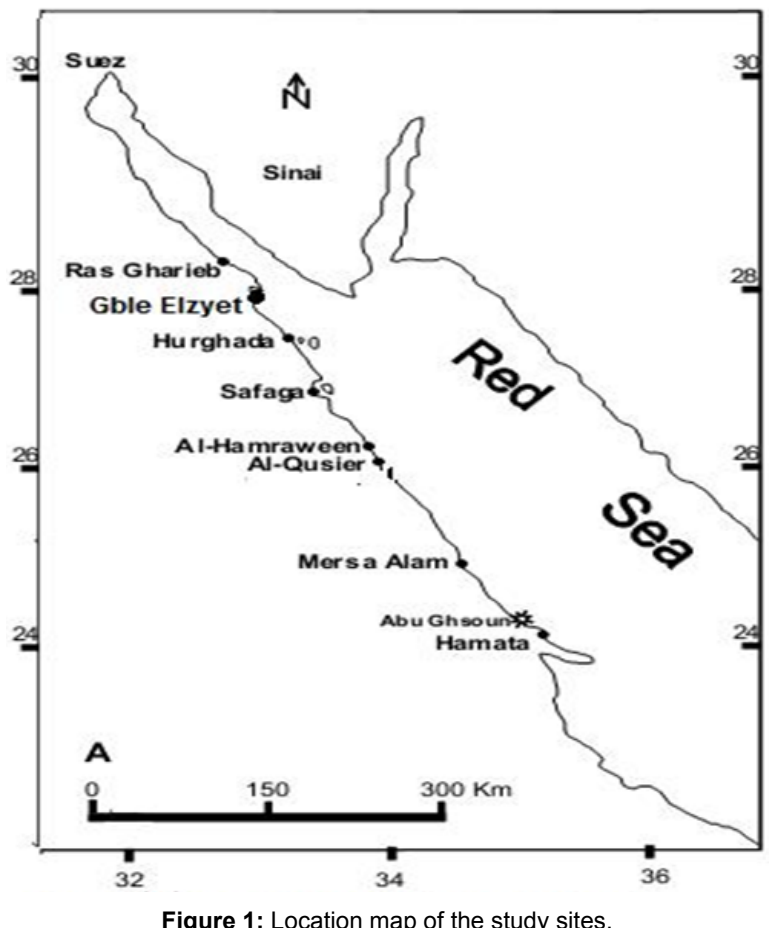

these are described in Tables 3 and 4. (Figure 2) presents photographs of each disease. Between reef differences in prevalence were significant (ANOVA; F $=10.777, \mathrm{p}<0.0001$ ). Sites closed to oil pollution (sites 1 and 2) displayed much higher levels of disease prevalence (25.3 \pm 8.32 and $18.5 \pm 3.1$, respectively), than site 3 that close to landfilling (12.9 \pm 2.1 ). The maximum percent of dead corals were also showed at sites 1 and $2(25.3 \pm 8.3$ and $18.3 \pm 5.7$, respectively), while the lowest one was at site $3(19.5 \pm 4.3)$. However, sites 1 and 2 recorded the highest percent cover of soft coral; they recorded the lowest percent of live hard corals.

A total of 12 coral diseases were detected on transects on the reefs of three studied sites. The maximum number of coral diseases was recorded at site 1 ( 10 coral diseases), while the minimum one was at site 3 (5 coral diseases). However the site having the lowest number of coral diseases (site 3 ) is characterized by the highest diversity (Simpson's Index $=0.081)$ and highest percentage cover of life coral $(35.2 \pm 11.4)$. Despite, the coral disease atrementous necrosis were not recorded at

\begin{tabular}{|c|c|c|c|c|c|c|c|c|c|}
\hline Sites & Simpson's Ind & NCD & \multicolumn{4}{|c|}{ Percent substrate composition } \\
\hline & & & DP & DCC & LHC & DC & SC & S\&R & Algae and Sea grass \\
\hline $\mathbf{1}$ & 0.17 & 10 & $23.3 \pm 3.2$ & $16.2 \pm 5.2$ & $20.1 \pm 5.4$ & $25.3 \pm 8.3$ & $21.2 \pm 6.4$ & $9.7 \pm 2.3$ & $7.5 \pm 1.7$ \\
\hline $\mathbf{2}$ & 0.12 & 8 & $18.5 \pm 3.1$ & $14.3 \pm 4.1$ & $27.2 \pm 6.3$ & $22.8 \pm 6.7$ & $18.3 \pm 5.7$ & $9.1 \pm 2.2$ & $8.3 \pm 1.9$ \\
\hline $\mathbf{3}$ & 0.081 & 5 & $12.9 \pm 2.1$ & $11.2 \pm 3.6$ & $35.2 \pm 11.4$ & $19.5 \pm 4.3$ & $12.7 \pm 4.5$ & $12.5 \pm 3.1$ & $8.9 \pm 1.8$ \\
\hline
\end{tabular}

Table 2: Site descriptions of reefs surveyed for disease. NCD = Number Coral Disease; DP = Disease Prevalence; DCC = Disease Coral Percent Cover; LHC = Live Hard Coral; DC $=$ Dead Coral; SC $=$ Soft Corals; $S$ and $\mathrm{R}=$ Sediments and Rocks. Percent substrate composition values are mean \pm SE. Simpson's index values close to 0 signify higher diversity and those approaching 1 signify lower diversity. 
Citation: Al-Hammady MAM, Mohamed MH (2016) Distribution and Disease Prevalence of Coral Associated Bacteria at Some Impacted Red Sea Reefs. J Biodivers Endanger Species 4: 158. doi:10.4172/2332-2543.1000158

Page 3 of 6

\begin{tabular}{|c|c|c|c|c|c|}
\hline Site 1 & Coral disease & Host species & DP & DCC & Remarks \\
\hline & \multirow{6}{*}{$\begin{array}{l}\text { White band } \\
\text { disease }\end{array}$} & Porites lutea & 0.2 & 0.3 & \multirow{6}{*}{$\begin{array}{l}\text { Mechanical } \\
\text { breaking } \\
\text { Aggressive } \\
\text { filamentous } \\
\text { algal } \\
\text { overgrowth }\end{array}$} \\
\hline & & Montipora verrucosa & 0.1 & 0.2 & \\
\hline & & Stylophora pistillata & 0.4 & 0.4 & \\
\hline & & Acropora humilis & 0.1 & 0.2 & \\
\hline & & Millepora dichotoma & * & * & \\
\hline & & Total & 0.8 & 1.1 & \\
\hline & \multirow{4}{*}{$\begin{array}{l}\text { White spots } \\
\text { disease }\end{array}$} & Porites rus & 0.4 & 0.5 & \multirow{4}{*}{$\begin{array}{l}\text { Gastropod } \\
\text { boring } \\
\text { Gastropod } \\
\text { drilling }\end{array}$} \\
\hline & & Astreopora myriophthalma & 0.1 & 0.3 & \\
\hline & & Porites solida & 0.5 & 0.5 & \\
\hline & & Total & 1 & 1.3 & \\
\hline & \multirow{5}{*}{$\begin{array}{l}\text { White } \\
\text { patches }\end{array}$} & Acropora valida & 0.2 & 0.5 & \multirow{5}{*}{$\begin{array}{l}\text { Parrot fish } \\
\text { predation }\end{array}$} \\
\hline & & Acropora hemprichi & 0.3 & 0.3 & \\
\hline & & Favites flexusa & 0.8 & 1 & \\
\hline & & Acropora tenuis & 0.2 & 0.3 & \\
\hline & & Total & 1.5 & 2.3 & \\
\hline & \multirow{8}{*}{$\begin{array}{c}\text { Atramentous } \\
\text { necrosis }\end{array}$} & Millepora platyphyla & 0.1 & 0.3 & \multirow{8}{*}{$\begin{array}{l}\text { Mechanical } \\
\text { breaking } \\
\text { Vermetidae } \\
\text { predation } \\
\text { Tridacna } \\
\text { boring } \\
\text { Gastropod } \\
\text { drilling }\end{array}$} \\
\hline & & Millepora dichotoma & * & * & \\
\hline & & Porites lutea & 1.3 & 1.6 & \\
\hline & & Lobophyllia corymbosa & 0.2 & 0.3 & \\
\hline & & Favites flexusa & 1.1 & 1.3 & \\
\hline & & Acropora tenuis & 0.5 & 0.7 & \\
\hline & & Goniasatrea pectinata & * & * & \\
\hline & & Total & 3.2 & 4.2 & \\
\hline & \multirow{5}{*}{ Brown band } & Montipora informis & 0.3 & 0.5 & \multirow{5}{*}{$\begin{array}{l}\text { Gastropod } \\
\text { drilling } \\
\text { Vermetidae } \\
\text { predation }\end{array}$} \\
\hline & & Montipora verrucosa & * & * & \\
\hline & & Porites lutea & 0.6 & 0.7 & \\
\hline & & Favites flexusa & 0.4 & 0.6 & \\
\hline & & Total & 1.3 & 1.8 & \\
\hline & \multirow{4}{*}{$\begin{array}{c}\text { Pigmentation } \\
\text { response }\end{array}$} & Stylophora pistillata & 0.3 & 1 & \multirow{4}{*}{$\begin{array}{c}\text { Ciliate } \\
\text { infection } \\
\text { Mechanical } \\
\text { breaking }\end{array}$} \\
\hline & & Acropora hemprichi & * & * & \\
\hline & & Porites rus & 0.1 & 0.2 & \\
\hline & & Total & 0.4 & 1.2 & \\
\hline & \multirow{6}{*}{$\begin{array}{c}\text { Partial } \\
\text { bleaching }\end{array}$} & Goniastrea & * & * & \multirow{6}{*}{$\begin{array}{l}\text { Mechanical } \\
\text { breaking } \\
\text { Aggressive } \\
\text { filamentous } \\
\text { algal } \\
\text { overgrowth }\end{array}$} \\
\hline & & Porites rus & 1.1 & 1.7 & \\
\hline & & Stylophora pistillata & 1 & 1.5 & \\
\hline & & Acropora tenuis & 0.3 & 0.5 & \\
\hline & & Montipora informis & * & * & \\
\hline & & Total & 2.4 & 3.7 & \\
\hline & \multirow{6}{*}{$\begin{array}{c}\text { Skeletal } \\
\text { eroding band }\end{array}$} & Platygyra daedalea & 0.8 & 1.2 & \multirow{6}{*}{$\begin{array}{l}\text { Drupella } \\
\text { predation } \\
\text { Gastropod } \\
\text { boring } \\
\text { Mechanical } \\
\text { breaking }\end{array}$} \\
\hline & & Montipora informis & 0.3 & 0.5 & \\
\hline & & Porites lutea & 0.7 & 0.9 & \\
\hline & & Stylophora pistillata & 0.8 & 1 & \\
\hline & & Favites flexusa & 0.2 & 0.3 & \\
\hline & & Total & 2.8 & 3.9 & \\
\hline & \multirow{5}{*}{$\begin{array}{l}\text { Dark spots } \\
\text { disease }\end{array}$} & Porites solida & 0.6 & 0.9 & \multirow{5}{*}{$\begin{array}{l}\text { Aggressive } \\
\text { coralline alga } \\
\text { overgrowth } \\
\text { Gastropod } \\
\text { boring } \\
\text { Mechanical } \\
\text { breaking }\end{array}$} \\
\hline & & Stylophora pistillata & 0.5 & 0.8 & \\
\hline & & Acropora humilis & 0.1 & 0.2 & \\
\hline & & Leptoseris incrustans & 0.1 & 0.2 & \\
\hline & & Total & 1.3 & 2.1 & \\
\hline & & Pavona explanulata & * & * & \\
\hline & & Stylophora pistillata & 0.6 & 0.8 & $\begin{array}{l}\text { Parrot fish } \\
\text { predation }\end{array}$ \\
\hline & wasting & Porites solida & 0.5 & 0.7 & Aggressive \\
\hline & & Echinopora gemmacea & 0.3 & 0.2 & filamentous \\
\hline & & Total & 1.4 & 1.7 & $\begin{array}{c}\text { algal } \\
\text { overgrowth }\end{array}$ \\
\hline & Total & & 16.2 & 23.3 & \\
\hline
\end{tabular}

\begin{tabular}{|c|c|c|c|c|c|}
\hline Site 2 & Coral disease & Host species & DP & DCC & Remarks \\
\hline & \multirow{5}{*}{$\begin{array}{l}\text { White band } \\
\text { disease }\end{array}$} & Porites lutea & 0.4 & 0.23 & \multirow{5}{*}{$\begin{array}{l}\text { Mechanical } \\
\text { breaking } \\
\text { Aggressive } \\
\text { filamentous } \\
\text { algal } \\
\text { overgrowth } \\
\text { Gastropod } \\
\text { boring }\end{array}$} \\
\hline & & Montipora verrucosa & 0.2 & 0.1 & \\
\hline & & Stylophora pistillata & 0.3 & 0.17 & \\
\hline & & Acropora humilis & 0.2 & 0.1 & \\
\hline & & Total & 1.1 & 0.6 & \\
\hline & \multirow{4}{*}{$\begin{array}{l}\text { Dark spots } \\
\text { disease }\end{array}$} & Porites rus & 0.7 & 0.6 & \multirow{4}{*}{$\begin{array}{l}\text { Gastropod } \\
\text { drilling, } \\
\text { coralline algal } \\
\text { overgrowth } \\
\text { Gastropod } \\
\text { boring } \\
\text { Mechanical } \\
\text { breaking }\end{array}$} \\
\hline & & Astreopora myriophthalma & 0.3 & 0.2 & \\
\hline & & Porites solida & 0.5 & 0.6 & \\
\hline & & Total & 1.5 & 1.4 & \\
\hline & \multirow{5}{*}{$\begin{array}{l}\text { White } \\
\text { patches }\end{array}$} & Acropora valida & 0.2 & 0.3 & \multirow{5}{*}{$\begin{array}{c}\text { Parrot fish } \\
\text { predation } \\
\text { Aggressive } \\
\text { filamentous } \\
\text { algal } \\
\text { overgrowth }\end{array}$} \\
\hline & & Acropora hemprichi & 0.5 & 0.65 & \\
\hline & & Favites flexusa & 0.6 & 0.7 & \\
\hline & & Acropora tenuis & 0.1 & 0.15 & \\
\hline & & Total & 1.4 & 1.8 & \\
\hline & \multirow{7}{*}{$\begin{array}{c}\text { Atramentous } \\
\text { necrosis }\end{array}$} & Millepora platyphyla & 0.2 & 0.09 & \multirow{7}{*}{$\begin{array}{c}\text { Mechanical } \\
\text { breaking } \\
\text { Tridacna } \\
\text { boring } \\
\text { Vermetidae } \\
\text { predation } \\
\text { Gastropod } \\
\text { drilling }\end{array}$} \\
\hline & & Porites lutea & 1.7 & 1.3 & \\
\hline & & Lobophyllia corymbosa & 0.5 & 0.31 & \\
\hline & & Favites flexusa & 1.4 & 0.4 & \\
\hline & & Acropora tenuis & 0.4 & 0.2 & \\
\hline & & Goniasatrea pectinata & 0.3 & 0.1 & \\
\hline & & Total & 4.5 & 2.4 & \\
\hline & \multirow{5}{*}{ Brown band } & Montipora informis & 0.2 & 0.3 & \multirow{5}{*}{$\begin{array}{l}\text { Vermetidae } \\
\text { predation }\end{array}$} \\
\hline & & Montipora verrucosa & 0.4 & 0.3 & \\
\hline & & Porites lutea & 0.7 & 0.4 & \\
\hline & & Favites flexusa & 0.3 & 0.2 & \\
\hline & & Total & 1.6 & 1.2 & \\
\hline & \multirow{4}{*}{$\begin{array}{c}\text { Pigmentation } \\
\text { response }\end{array}$} & Stylophora pistillata & 1.5 & 1.3 & \multirow{4}{*}{$\begin{array}{l}\text { Vermetidae } \\
\text { predation } \\
\text { Gastropod } \\
\text { drilling } \\
\text { Mechanical } \\
\text { breaking }\end{array}$} \\
\hline & & Acropora hemprichi & 0.8 & 1.1 & \\
\hline & & Porites rus & * & * & \\
\hline & & Total & 2.3 & 2.4 & \\
\hline & \multirow{6}{*}{$\begin{array}{c}\text { Partial } \\
\text { bleaching }\end{array}$} & Goniastrea retiformis & 0.4 & 0.3 & \multirow{6}{*}{$\begin{array}{c}\text { Aggressive } \\
\text { filamentous } \\
\text { algal } \\
\text { overgrowth } \\
\text { Mechanical } \\
\text { breaking }\end{array}$} \\
\hline & & Porites rus & 1.6 & 0.9 & \\
\hline & & Stylophora pistillata & 1.2 & 0.8 & \\
\hline & & Acropora tenuis & * & * & \\
\hline & & Montipora informis & 0.9 & 0.6 & \\
\hline & & Total & 4.1 & 2.6 & \\
\hline & \multirow{6}{*}{$\begin{array}{c}\text { Skeletal } \\
\text { eroding band }\end{array}$} & Platygyra daedalea & * & * & \multirow{6}{*}{$\begin{array}{l}\text { Drupella } \\
\text { predation } \\
\text { Gastropod } \\
\text { boring } \\
\text { Mechanical } \\
\text { breaking }\end{array}$} \\
\hline & & Montipora informis & 0.3 & 0.2 & \\
\hline & & Porites lutea & 0.4 & 0.32 & \\
\hline & & Stylophora pistillata & 1.1 & 0.97 & \\
\hline & & Favites flexusa & 0.2 & 0.11 & \\
\hline & & Total & 2 & 1.6 & \\
\hline & Total & & 18.5 & & 14.3 \\
\hline
\end{tabular}


Citation: Al-Hammady MAM, Mohamed MH (2016) Distribution and Disease Prevalence of Coral Associated Bacteria at Some Impacted Red Sea Reefs. J Biodivers Endanger Species 4: 158. doi:10.4172/2332-2543.1000158

Page 4 of 6

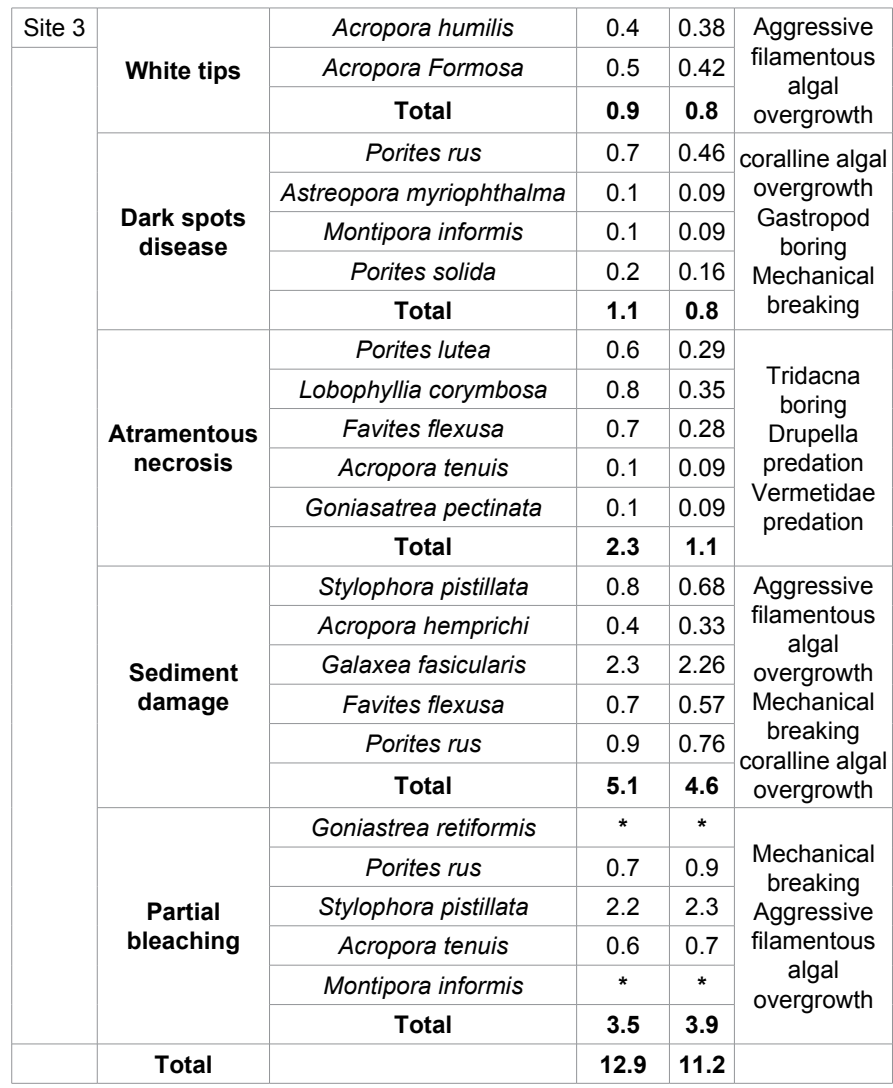

Table 3: Percent disease prevalence and percent cover of disease affecting coral reef species at the studied sites. DP = Disease Prevalence; DCC = Disease Coral Percent Cover.

\begin{tabular}{|c|c|c|c|}
\hline Tests & Result & Tests & Result \\
\hline Colony shape & Round & Colony colour & White Creamy \\
\hline Gram stain & -Ve rods & Motility & $+\mathrm{Ve}$ \\
\hline Cytochrome oxidase & $+\mathrm{Ve}$ & Catalase & $+\mathrm{Ve}$ \\
\hline Growth in $0 \% \mathrm{NaCl}$ & - & Growth in $1.5 \% \mathrm{NaCl}$ & + \\
\hline $3 \% \mathrm{NaCl}$ & + & $6 \% \mathrm{NaCl}$ & + \\
\hline \multicolumn{4}{|l|}{ API20E } \\
\hline ONPG & + & Gelatin hydrolysis & - \\
\hline Arginine dihydrolase & - & Glucose & - \\
\hline Lysine decarboxylase & + & Manitol & - \\
\hline Ornithine decarboxylase & - & Inositol & - \\
\hline Citrate & - & Sorbitol & - \\
\hline $\mathrm{H} 2 \mathrm{~S}$ & - & Rhaminose & - \\
\hline Urea hydrolysis & + & Sucrose & - \\
\hline Tryptophanedeaminase & - & Malonate & - \\
\hline Indole & - & Adonitol & - \\
\hline Voges-Proskauer & - & Arabinose & - \\
\hline Raffinose & - & Salicin & - \\
\hline Xylose & - & Lactose & - \\
\hline
\end{tabular}

Table 4: Results of the biochemical characterization of the Vibrio fischeri isolates.

site 3 , it attained the highest prevalence percentage at sites 1 and $2(3.2$ and 4.5 , respectively). On the other hand, the Sediment damage disease recorded the highest prevalence percentage at site 3 (5.1), but the same disease did not recorded at sites 1 and 2 Diseases having lowest percentage cover are white band disease (sites 1 and 2) and white tips disease (Figure 3).
We found 99 coral braches, representing 20 species affected by at least 12 diseases. The most commonly distributed disease (atrementous necrosis) infected five corals in siteland six corals in site 2. However, the least commonly distributed disease (white tips) infected only two corals (Acropora humilis and Acropora formosa) at site 3. The genus Porites at sites was particularly vulnerable to all diseases we observed; indeed, white patches disease was the only disease noted that did not affect the genus. However, Galaxea fasicularis at site 3 recorded the highest percent cover of sediment damage disease. Coral disease atramentous necrosis is associated with Vermetidae predation, and in many cases with Tridacna boring. However, Vermetidae predation is also associated with tissue discoloration (non-white pigmentation response) while Drupella predation is associated with skeletal eroding band. Aggressive filamentous algal over growth is associated with Sediment damage disease at site 3 .

\section{Isolation and characterization of the bacterial strains}

54 bacterial strains have been isolated from the infected Stylophora pistillata, Porites sp., and Acropora sp. by different diseases. Of which; 38 isolates were not biochemically similar and identified through their morphology, conventional biochemical tests and API20E system tests as Vibrio fischeri isolates (Table 4), and as unknown a typical vibrio species (16 isolates).
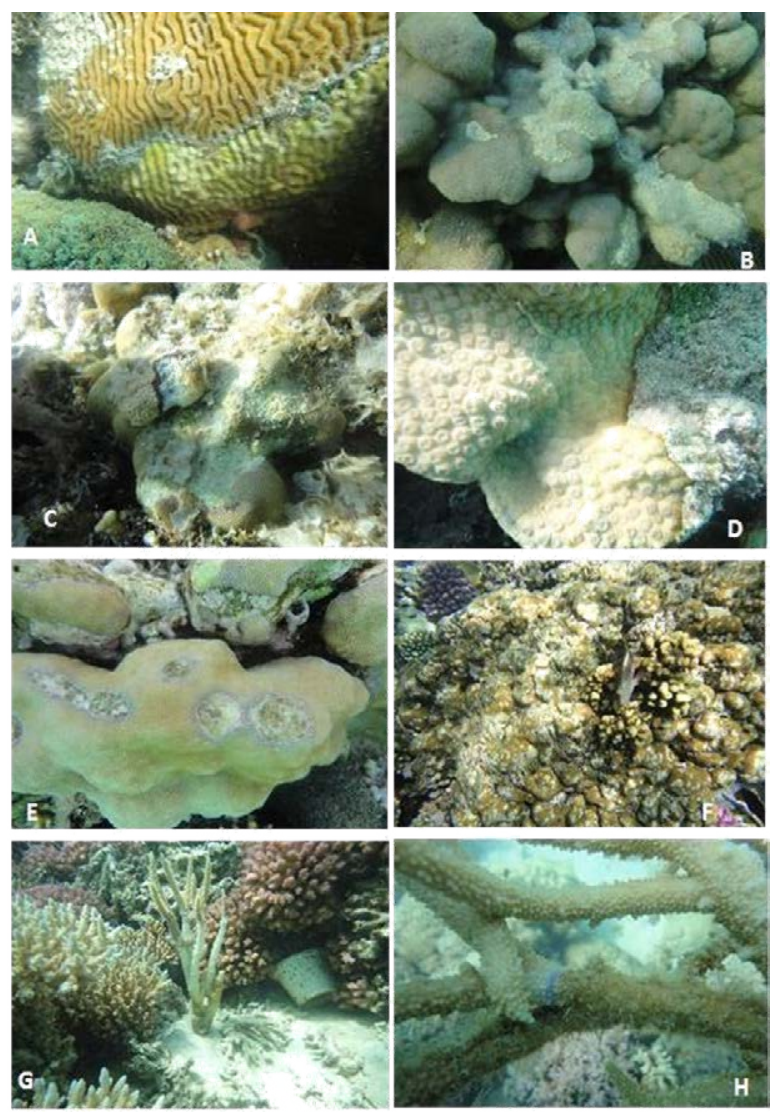

Figure 2: Most common diseases and syndromes in Red Sea. Compromised tissue responses affecting massive coral (A) Platygyra and (B) Porites, Black band disease affecting massive coral (C) Montipora and encrusting coral (D) Echinopora, Pigmentation response affecting massive coral (E) Porites, Ulcerative white spots affecting (F) Porites, White syndrome affecting (G) Acropora and White band disease affecting $(\mathrm{H})$ Acropora. 

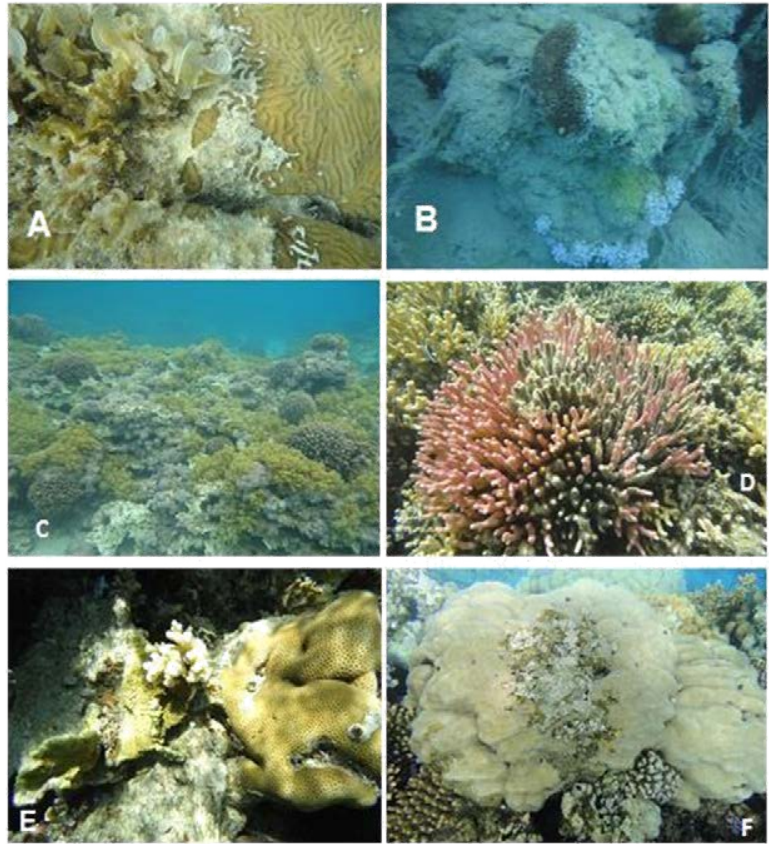

Figure 3: Sediment damage on (A) Platygera and (B) Galaxea in site 1. Over growth of (C) soft corals and partial dead colony of (D) Stylophora in site 2. (E) Corallivorous Vermetidae on Favia and (F) Drupella on Porites in site 3.

\section{Discussion}

Our surveys have provided baseline information on the prevalence of coral disease affecting reefs in the Red Sea, a country within the global center of coral reef biodiversity. As it is obvious from the present study, diseases prevalence were significant differences between reefs, of which reefs closed to oil pollution (sites 1 and 2) displayed much higher levels of disease prevalence, \% cover of diseases and \% cover of dead corals, than reef close to landfilling (site 3 ). This coincides with the result of $\mathrm{Al} \mathrm{Hammady}[7,23]$, that oil pollution induced coral disease, moderately and severe bleaching and cause reproduction damage. However, Gong et al. [24] identified a knowledge gaps that needs further research to facilitate sounder assessment of fate and effect of oil pollution on marine ecosystem. Furby et al. [2] reported a strong correlation between the presence of lesioned corals and the elevation of ammonium concentrations, and also reported changes in microbial communities with decreased water quality. Disease causation may due to pathogens, environmental stressors, or a combination of biotic and abiotic factors. Biotic diseases are caused by the infection of pathogenic microorganisms such as viruses, bacteria and fungi $[4,6]$. Abiotic diseases result from both natural and human induced environmental stressors including change in ambient conditions or exposure to pollutants [1]. Moreover, biotic diseases may be associated with environmental stressors that: (1) hinder the resistance of host organisms, (2) promote growth and virulence of pathogens, (3) trigger the pathogenic process, or (4) increase the rate of disease transmission $[8,9]$. While, abiotic diseases may be exacerbated by secondary opportunistic infections [4].

The site having the lowest number of coral diseases (site 3) is characterized by the highest percentage cover of coral disease sediment damage, indicating space monopolization and outbreak of this disease. The higher sedimentation at site 3 may increase the percent cover of sediment damage coral disease at the expense of disease number. This could be due to increase coral mortality with increased sedimentation, increasing the available substrate or space for diverse diseases. On the other hand, decreased resistance of the host coral caused by environmental threats could increase opportunistic diseases [25] leading finally to increased coral mortality [26]. Changes in the population size (e.g. percentage cover), growth and reproduction of a community's primary producers (e.g. algae) and major framework builders will have impacts on the community. These changes are especially relevant given the longevous age structure of corals and, as compared to macro algae, their relatively slow coral recruitment [27]. This agrees with the present results in which the highest percentage cover of algae / sea grasses is associated with the highest percentage cover of sediment damage coral diseases (site 3), but the lowest percentage cover of each of algae / sea grasses and sediments is associated with the highest percentage cover of coral diseases (sites 1 and 2). In contrast, Ammar et al. [1] found that the highest percentage cover of algae / sea grasses is associated with the highest percentage cover of coral diseases at Eel Garden at Dahabnorthern Red Sea. Sheridan et al. [17] reported that corals from reefs affected by river discharge and terrestrial sediments were more affected by white syndrome than reefs located far from any source of terrestrial runoff. Terrestrial runoff-affected reefs also displayed a wider diversity of coral species affected by this disease.

At present, the pathogenic bacteria Vibrio sp. was isolated the from atramentous necrosis disease. Ritchie and Smith [28] reported a similar result, that white band disease is always associated with Vibrio charcharia, but attempts to fulfill Koch's postulates with this bacterium have been unsuccessful to date [28]. While, Ben-Haim and Rosenberg [3] used $16 \mathrm{~S}$ rDNA sequence and isolate the pathogenic bacterium Vibrio coralyticus as an new Vibrio genus from the diseased tissue of Pocillopora damicornis.

A link between snail predators and increased disease prevalence has been suggested by other studies. Antonius and Reigl [10] reported that, an outbreak of white syndrome in the Acroporids Red Sea coral was correlated with an outbreak of the corallivorous snail Drupella cornus. Moreover, Miller et al. [29] found that, the snail predator Drupella cornus is common on Florida acroporid corals, and many areas of the Caribbean [30]. Exposure to Hermodice carunculata (polychaete) infected with the bleaching pathogen Vibrio shiloi has been shown to induce bleaching in the Mediterraneancoral Oculina patagonica in laboratory aquaria [11]. H. carunculatais also a common predator of Acropora cervicornis in the Florida, feeding by engulfing a branch tip and digesting the coral tissue, leaving bare skeleton behind [31].

Threats to biodiversity are considered one of the major predicted impacts of new diseases and those infecting multiple species [12]. We expected a relationship between diversity and disease prevalence, as high prevalence of a disease with multiple hosts can lower diversity [8]. In contrast, a high diversity reef could be predicted to be more resistant to an infectious disease, if host species are less abundant. Our diversity calculations vary widely between sites and the reef with the highest diversity, sites 3 , had the healthiest reef community, and least coral disease prevalence. However, a previous report stated that most coral diseases affect only a few species [13]. Results from this study and other reports Richardson et al. [14], Green and Bruckner [15] and Weil et al. [16], show that the total number of species diseased is increased according to geographical location, and that host breadth of most diseases is wider than previously have been thought. The lowest diversity of coral reef at sites 1 and 2 could be explained by the fact that, soft corals at these sites, which are mostly abundant, common or frequent in contrast to stony corals which are mostly scarce. This seems 
that, soft corals have higher growth rate, and higher competition for space and recovery than stony corals [32]. This agrees with Benayahu and Loya [33] who found that soft corals are the major competitors overgrowing hard corals. Benayahu [34] stated that, soft corals compete for space with true stony corals and cause their death. Although one of our objectives was to examine the effect of reef health on disease prevalence, the rarity of truly healthy reefs within our sampling regions made it impossible to conduct such a comparison. A larger scale survey is needed to elucidate relationships between disease prevalence and reef health, water quality, hard coral cover and hard coral diversity. Thus, there appears to be a low correlation between reef health and disease out breaks and apparently healthy reefs show high prevalence of disease [13,35-37].

\section{Conclusion and Recommendation}

The present study found that impacted Red Sea reefs associated with diseases and syndromes. Moreover, sites closed to oil pollution displayed much higher levels of disease prevalence than site close to landfilling. The most commonly distributed disease was atramentous necrosis and the least one was white tips at all sites. The genus Porites was particularly vulnerable to all diseases. The pathogenic bacterium isolated from the diseased Stylophora pistillata, Porites sp., and Acropora sp. was Vibrio fischeri.

It is clear that research on coral disease pathogenesis requires more laboratory and field studies. Recommending directed research and education to fill these knowledge gaps. Continuous efforts at threated reefs are still needed to understand coral diseases necessary to contribute to the effective maintenance of coral reefs.

\section{Acknowledgement}

This investigation was done as a part of the 2013/2014.strategy of the National Institute of Oceanography and Fisheries-Red Sea branch.

\section{References}

1. Ammar MSA, Ashour F, Abdelazim H (2013) Coral disease distribution at Ras Mohammed and the Gulf of Aqaba, Red Sea, Egypt. Bioscience 5: 34-42.

2. Furby KA, Apprill AJ, Cervino M, Ossolinski JE, Hughen KA (2014) Incidence of lesions on Fungicide corals in the eastern Red Sea is related to water temperature and coastal pollution. Mar Environ Res J 98: 20-38.

3. Ben-Haim Y, Rosenberg E (2002) A novel Vibrio sp. pathogen of the coral Pocilloporadamicornis. Mar Biol 141: 47-55.

4. Peters EC (1997) Diseases of coral reef organisms. In: Birke-land C (ed) Life and death of coral reefs. Chapman and Hall, New York 114-139.

5. Taniguchi A, Yoshida T, Eguchi M (2014) Bacterial production is enhanced by coral mucus in reef systems. Exp Mar Biol Ecol J 461: 331-336.

6. Kinne O (1980) Diseases of marine animals: general aspects. In: Kinne O (ed) Diseases of marine animals, Vol 1. General aspects, Protozoa to Gastropoda John Wiley \& Sons, New York.

7. Al-Hammady MAM, Mahmoud (2013) The Effect of Expanding Coastal Urban, Industrial Centers, Ports and Tourism on the Red Sea Coral Reefs, Egypt. Proc. of the International Conference of Environmental Sciences (ICES) 207-221.

8. Kuta KG, Richardson LL (2002) Ecological aspects of black band disease of corals: relationships between disease incidence and environmental factors. Coral Reefs 21: 393-398.

9. Richardson LL, Kuta KG (2003) Ecological physiology of the black band disease cyanobacteria Phormidiumcorallyticum. FEMS. Microbial Ecol 43: 287-298.

10. Antonius A, Riegl B (1997) A possible link between coral diseases and a corallivorous snail (Drupellacornus) outbreak in the Red Sea. Atoll Res Bull 447: $1-9$

11. Sussman M, Loya $Y$, Fine M, Rosenberg $E$ (2003) The marine fire worm Hermodicecarunculatais a winter reservoir and spring-summer vector for the coral bleaching pathogen Vibrio shiloi. Environ Microbiol 5: 250-255.

12. Kim K, Dobson AP, Gulland FMD, Harvell CD (2003) Diseases and the conservation of marine biodiversity, Chap 9. In: Norse E, Crowder F (eds.) Marine conservation biology: The science of maintaining the sea's biodiversity. Island Press, Washington, DC.

13. Goreau TJ, Cervino J, Goreau M, Hayes R et al. (1998) Rapid spread of diseases in Caribbean coral reefs. Rev Biol Trop 46: 157-171.

14. Richardson LL, Goldberg WM, Carlton RG, Halas JC (1998) Coral disease outbreak in the Florida Keys: plague type II. Rev Biol Trop 46: 187-198.

15. Green EP, Bruckner AW (2000) The significance of coral disease epizootiology for coral reef conservation. Biol Conserve 96: 347-361.

16. Weil E, Urreiztieta I, Garzón-Ferreira J in press (2000) Geographic variability in the incidence of coral and octocoral diseases in the wider Caribbean. Proc 9th IntCoral Reef Symp.

17. Sheridan C, Baele JM, Kushmaro A, Fréjaville Y, Eeckhaut I (2014) Terrestrial runoff influences white syndrome prevalence in SW Madagascar. Mar Environ Res J 101: 44-51.

18. CRC Press, Boca Raton FL, Veron JEN (2000) Corals of the world 3: 477

19. Wallace C (1999) Staghorn corals of the world. CSIRO Publishing, Collingwood.

20. Rosenzweig ML (1995) Species diversity in space and time. Cambridge University Press, Cambridge.

21. Gil-Agudelo DL, Myers C, Smith GW, Kim K (2006) Changes in the microbial communities associated with Gorgoniaventalina during aspergillosis infection. Diseases of Aquatic Organisms 69: 89-94.

22. Nicky BB (2004) Bacteria from Fish and Other Aquatic Animals, CABI Publishing CAB International Wallingford Oxford shire OX10 8DE. UK 357.

23. Al-Hammady MAM (2011) Patterns of bleaching and fertility in the two Red Sea corals Stylophora pistillata and Acropora humilis as bio monitors of environmental impacts. Sci Facu Assiutunive 482.

24. Gong Y, Zhahho X, Cai Z, O'Reilly SE, Hao X, et al. (2014) A review of oil dispersed oil and sediment interactions in the aquatic environment: Influence on the fate, transport and remediation of oil spills. Mar Pollut Bull 79: 16-33.

25. Harvell CD, Kim K, Burkholder JM, Colwell RR, Epstein PR (1999) Emerging marine diseases. Climate links and anthropogenic factors. Science 285: 1051510.

26. Haapkyla J, Unsworth RKF, Seymour AS, Melbourne-Thomas J, Flavell M (2009) Spatiotemporal coral disease dynamics in the Wakatobi Marine National Park, South-East Sulawesi, Indonesia. Dis Aquat Org 87: 105-115.

27. Tougas JI, Porter JW (2002) Differential coral recruitment patterns in the Florida Keys. In: Porter JW, Porter KG. (eds) The Everglades, Florida Bay, and Coral Reefs of the Florida Keys.

28. Ritchie KB, Smith GW (1995) Carbon-source utilization patterns of cora associated marine heterotrophs. J Mar Biotechnol 3: 105-107.

29. Miller MW, Bourgue AS, Bohnsack JA (2002) An analysis of the loss of acroporid corals at Looe Key, Florida USA: 1983-2000. Coral Reefs 21: 179-182.

30. Bruckner AW, Bruckner RJ, Williams EH Jr (1997) Spread of a black-band disease epizootic through the coral reef sys-tem in St Ann's Bay Jamaica. Bull Mar Sci 61: 919-928.

31. Marsden JR (1962) A coral-eating polychaete. Nature 193: 598.

32. Ammar MSA, Ghobachi AA, Omran MA, Shabban AM (2007) Status of coral reef affected by different impacts in some sites of the Red Sea. Egypt 33: 224237.

33. Benayahu $Y$, Loya $Y$ (1981) Competition for space among coral reef sessile organisms at Eilat, Red Sea. Bull Mar Sci 31: 514-522.

34. Benayahu Y (1985) Faunistic composition and patterns in the distribution of soft corals (Octocorallia, Alcyonacea) along the coral reefs of Sinai Peninsula. Proc 5th Int., Coral Reef Cong Tahiti 97-103.

35. Jordan-Dahlgren E, Maldonado MA, Rodriguez-Martinez RE (2005) Diseases and partial mortality in Montastraeaannularis species complex in reefs with differing environ-mental conditions (NW Caribbean and Gulf of Mexico). Dis Aquat Org 63: 3-12.

36. Bruckner AW (2002) Priorities for effective management of coral diseases NOAA Tech Mem NMFS-OPR-22. Washington, DC.

37. Bythell JC, Barer MR, Cooney RP, Guest JR, O'Donnell AG, et al. (2002) Histopathological methods for the investigation of microbial communities associated with disease lesions in reef corals. Lett Appl Microbiol 34: 359-364. 